\title{
Identifikasi dan Eliminasi Pemborosan Aktivitas pada Proses Produksi Suku Cadang dengan Pendekatan Lean Manufacturing
}

\section{Identification and Elimination of Waste Activities in Sparepart Production Process using Approach Lean Manufacturing}

\author{
Agustian Suseno $^{1^{*}}$, Hengky ${ }^{1}$ \\ ${ }^{1}$ Program Studi Teknik Industri, Universitas Singaperbangsa Karawang, Jl. H. S. Ronggowaluyo, Telukjambe \\ Timur, Karawang 41361, Indonesia
}

Diterima: 26 Mei, 2019 / Disetujui: 30 Juli, 2019

\begin{abstract}
PT. Trijaya Teknik Karawang is a manufacturing company that produces spare parts, namely the piece pivot. The increased demand make the company parties need to analyze the ability to do the production to make it more effective and efficient in order to win the competition. Preliminary observations on the production floor they still present problems that are categorized as waste. Based on it, lean manufacturing Approach used to solve these problems. First of all the waste identified by mapping the flow of production using Value Stream Mapping (VSM). Then determined the dominant waste going through weighting waste using Waste Assesment Model (WAM) with the result that the inventory is the dominant waste. Next choose a detail mapping tools with Value Stream Analyze Tools (VALSAT) and determine the cause of waste inventory with fishbone diagrams that result, the causes of waste inventory is the breakdown of the machine, the operator of conduct material handling and less nimble, the distance between the machine and the system far, the production batch manufacture. Recommendations for improvements are the application of the system production of one-piece flow with investing buying transfer dies and adds to the human resources division maintenance. The identification of the problem causing factors of the dominant waste activity, namely waste inventory using Fishbone diagrams is lack of engine maintenance because it does not have a maintenance division and the production system used is batch manufacture that produces goods in lot size so that there are WIP parts in each production process.
\end{abstract}

Keywords: Lean Manufacturing, Value Stream Mapping, Waste Assesment Model, Value Stream Analyze Tools, Diagram Fishbone.

\begin{abstract}
ABSTRAK
PT. Trijaya Teknik Karawang merupakan perusahaan manufaktur salah satu produknya yaitu piece pivot. meningkatnya permintaan membuat pihak perusahaan perlu menganalisis kemampuan dalam melakukan produksi agar lebih efektif dan efisien guna memenangkan kompetisi. Hasil observasi awal pada lantai produksi terindikasi masih terdapat permasalahan yang dikategorikan sebagai pemborosan. Berdasarkan hal itu, Pendekatan lean manufacturing dipergunakan untuk menyelesaikan permasalahan tersebut. Pertama-tama pemborosan diidentifikasi dengan memetakan aliran produksi menggunakan Value Stream Mapping (VSM). Kemudian ditentukan pemborosan yang dominan terjadi, melalui pembobotan Waste Assesment Model (WAM) dengan hasil bahwa persediaan merupakan pemborosan dominan. Selanjutnya memilih detail mapping tools dengan Value Stream Analyze Tools (VALSAT) dan menentukan penyebab terjadinya pemborosan persediaan dengan diagram fishbone yang hasilnya yaitu penyebab pemborosan persediaan adalah breakdown mesin, operator melakukan material handling dan kurang cekatan, jarak antar mesin cukup jauh, dan sistem produksinya batch manufacture. Rekomendasi perbaikan yang dapat diusulkan yaitu penerapan sistem produksi one-piece flow dengan berinvestasi membeli mesin stamping transfere dies dan menambah sumber daya manusia untuk membangun divisi maintenance. Hasil identifikasi faktor penyebab masalah dari aktivitas pemborosan yang dominan yaitu pemborosan persediaan dengan menggunakan diagram fishbone adalah kurang perawatan mesin karena tidak memiliki divisi maintenance dan sistem produksi yang dipakai adalah batch yang memproduksi barang secara lot size sehingga terdapat WIP part pada setiap proses produksi.
\end{abstract}

Kata Kunci: Lean Manufacturing, Value Stream Mapping, Waste Assesment Model, Value Stream Analyze Tools, Diagram Fishbone

*email: susenoagustian@gmail.com 


\section{PENDAhUluaN}

Pertumbuhan produksi industri manufaktur besar dan sedang pada triwulan III2018, mengalami peningkatan sebesar 4.13\% (qto-q) terhadap triwulan II-2018 (Badan Pusat Statistik, 2018). Hal tersebut mengakibatkan dunia industri manufaktur berlomba-lomba dalam melakukan perbaikan dan peningkatan kinerja guna dapat bertahan dalam persaingan dunia industri. PT. Trijaya Teknik Karawang merupakan salah satu perusahaan manufaktur yang berlokasi di Karawang Timur, Provinsi Jawa Barat, Indonesia. Perusahaan ini memproduksi berbagai macam komponen sparepart kendaraan bermotor yang melalui proses stamping. Komponen sparepart yang dimaksud antara lain side stand, dampel pedal, piece pivot, dan masih banyak lagi. Perusahaan ini tidak hanya bergerak melayani produksi komponen melalui proses stamping, namun juga bergerak di bidang fabrikasi dan machining. Pada kurun waktu beberapa periode ini menurut bagian penjualan, perusahaan mengalami peningkatan permintaan yang terus bertambah, dengan meningkatnya permintaan maka tingkat produksinya pun otomatis meningkat. Oleh karena itu, hal ini dianggap perlu untuk membuat sebuah analisis terkait kemampuan perusahaan dalam melakukan proses produksi.

Berdasarkan observasi awal di lapangan, ditemukan adanya penumpukan bahan baku dan bahan setengah jadi (Work In Process/WIP) pada lantai produksi piece pivot, serta gerakan yang tidak perlu pada tahap produksi seperti mengumpulkan hasil proses yang bertebaran. Untuk itu, faktor faktor yang ikut berkonstribusi di dalamnya, seperti sumber daya manusia, mesin, material, dan lain sebagainya harus senantiasa dievaluasi apakah masih relevan dengan kondisi bisnis yang dijalankan atau perlu dilakukan revisi/perbaikan (Rawabdeh, 2005).

Proses perbaikan atau efisiensi yang dilakukan hendaknya sesuai dengan kemampuan dan sumber daya yang ada di perusahaan. Karena itu, diperlukan pendekatan yang relatif sederhana dan terstruktur dengan baik agar mudah dipahami yaitu pendekatan lean manufacturing. Metode lean manufacturing ini menolong perusahaan untuk menjadi kompetitif, khususnya dalam hal pengurangan pemborosan dalam proses operasional perusahaan. Lean manufacturing harus dimulai dengan pemahaman yang sempurna tentang bisnis, tidak hanya proses produksi dan aliran material tapi juga aliran informasi (Womack dan Jones, 2003).

Salah satu alat yang sangat bermanfaat dan juga sederhana yang sering digunakan untuk menangkap informasi ini adalah Value Stream Mapping (Rother dan Shook, 1999). Berbagai macam informasi secara baik ditampilkan dalam Current State Map, dengan tujuan utama untuk mengerti dan mendokumentasikan (semua proses) keadaan saat ini dengan semua isu/persoalan didalamnya sehingga kemudian mendorong terjadinya improvement dalam proses itu sendiri (Nash dan Poling, 2008) Sementara itu, alat yang dapat membantu untuk mengetahui atau mengidentifikasi pemborosan yaitu Waste Assesment Model (WAM). WAM merupakan suatu model yang dikembangkan untuk menyederhanakan pencarian dari permasalahan pemborosan dan mengindentifikasi untuk mengeliminasi pemborosan (Rawabdeh, 2005). WAM mengurutkan pembobotan pemborosan dari yang tertinggi hingga terendah sehingga mampu memberikan konstribusi untuk mencapai hasil yang akurat dalam mengidentifikasi pemborosan (Utama, Dewi dan Mawarti, 2016).

Implementasi lean manufacturing sudah dilakukan pada berbagai jenis industri. Pada industri kertas, pendekatan ini berhasil mengurangi waktu tunggu saat kedatangan bahan baku sampai proses produksi sehingga dapat mereduksi lead time sebesar 72 menit (Fanani dan Singgih, 2011). Pendekatan ini juga digunakan untuk mengurangi waktu produksi di industri tekstil sebesar $7.15 \%$ melalui pengurangan aktivitas-aktivitas yang termasuk Non Value Added (NVA) (Kusuma, 2010).

Penelitian ini dilakukan pada industri suku cadang untuk mengidentifikasi gambaran aktivitas pemborosan menggunakan Value Stream Mapping (VSM) dan WAM. Selain itu, penelitian ini juga membahas tentang penyebab terjadinya pemborosan sehingga dapat memberikan usulan perbaikan untuk mengeliminasi pemborosan yang terjadi pada proses produksi piece pivot, dalam upaya meningkatkan produktivitas yang efektif dan efisien. Faktor pembeda dari penelitian ini dengan peneliti terdahulu yaitu proses identifikasi terhadap pemborosan, dilakukan 
dengan menggunakan bantuan WAM, guna mencapai hasil yang akurat dalam mengidentifikasi pemborosan. Sementara itu, dari segi objek penelitianya, penelitian ini mengidentifikasi dan mengeliminasi aktivitas pemborosan pada industri manufaktur yang memproduksi suku cadang.

\section{METODOLOGI}

Penelitian ini merupakan penelitian dengan pendekatan kualitatif menggunakan analisis kuantitatif untuk beberapa data yang berupa hasil observasi atau record dari perusahaan. Peneliti melakukan observasi langsung dan penggalian informasi terhadap lingkup penelitian dengan melakukan wawancara dari sumber-sumber yang telah dipastikan mengetahui informasi yang dibutuhkan oleh peneliti. Informan terpilih yaitu manajer produksi yang memangku kepentingan dan yang mengetahui mendalam mengenai proses produksi di perusahaan. Dengan seperti itu peneliti dapat mengetahui masalah yang terjadi pada kondisi saat ini, sehingga dapat menetapkan objek penelitian ini dan menetapkan tujuan penelitian, guna mendapatkan rekomendasi perbaikan masalah terhadap kondisi yang terjadi.

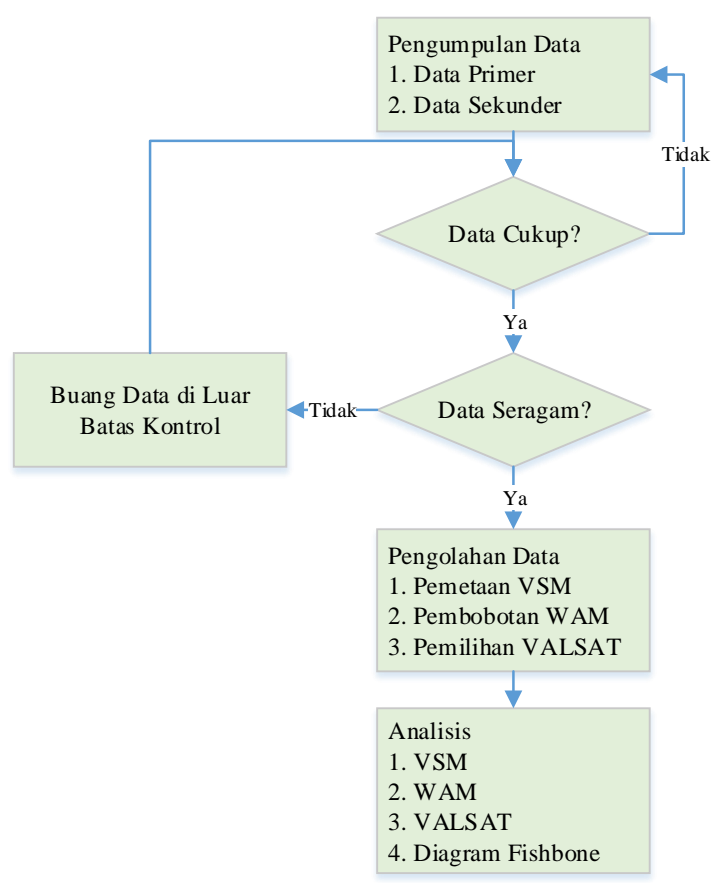

Gambar 1. Metodologi Penelitian

Gambar 1 menggambarkan alur proses atau tahapan-tahapan pengolahan data aktivitas pada proses produksi suku cadang dengan pendekatan lean manufacturing. Tahap pengumpulan data merupakan tahap mengumpulkan data yang dibutuhkan untuk penelitian, diantaranya: aliran proses produksi, cycle time, pembobotan pemborosan melalui kuesioner, dll. Kemudian data yang telah didapat dilakukan uji kecukupan data dan uji keseragaman data, untuk mengetahui apakah data cukup mewakili populasi dan masuk ke dalam batas kontrol. Pada penelitian ini, digunakan tingkat kenyakinan $95 \%$ dan tingkat ketelitian 5\%.

Setelah mendapat data yang mendukung penelitian, kemudian yang pertama dilakukan yaitu memetakan aliran proses produksi dengan menyusun current state VSM, kedua yaitu melakukan identifikasi pemborosan yang dominan terjadi dengan metode WAM, model ini model ini akan mengurutkan pembobotan pemborosan dari yang tertinggi hingga terendah. Dengan tahapan pembobotan: Melakukan pembobotan terhadap hubungan antar pemborosan dengan Waste Relationship Matrix (WRM) seperti ditunjukkan pada Tabel 1. WRM merupakan matriks yang terdiri dari baris dan kolom. Baris menunjukan pengaruh tiap pemborosan pada keenam tipe pemborosan lainnya. Kolom menunjukan pemborosan yang dipengaruhi oleh keenam pemborosan lainnya. Diagonal matriks menunjukan nilai hubungan yang tertinggi. Simbol yang terdapat dalam WRM menandakan jenis hubungan antar pemborosan berdasarkan pembobotan range score pengaruh pada Tabel 2.

Tabel 1. Waste Relationship Matrix

\begin{tabular}{cccccccc}
\hline F/T & O & I & D & M & T & P & W \\
\hline O & A & I & U & O & A & X & I \\
I & I & A & U & E & E & X & X \\
D & U & E & A & I & O & X & I \\
M & X & I & U & A & X & I & U \\
T & U & O & U & A & A & X & O \\
$\mathbf{P}$ & U & O & U & E & X & A & O \\
W & U & O & U & X & X & X & A \\
\hline
\end{tabular}

Tabel 2. Range Score Pembobotan

\begin{tabular}{|llc}
\multicolumn{1}{c}{ Range } & \multicolumn{1}{c}{ Jenis Hubungan } & Simbol \\
\hline $\mathbf{1 7 - 2 0}$ & Absolutely Necessary & $\mathbf{A}$ \\
\hline $\mathbf{1 3 - 1 6}$ & Especially Important & $\mathbf{E}$ \\
\hline $\mathbf{9 - 1 2}$ & Important & I \\
$\mathbf{5 - 8}$ & Ordinary Closeness & $\mathbf{O}$ \\
\hline $\mathbf{1 - 4}$ & Unimportant & $\mathbf{U}$ \\
\hline
\end{tabular}


Tabel 3. Jenis dan Jumlah Pertanyaan

\begin{tabular}{llc}
\hline $\boldsymbol{i}$ & Type of question $(\boldsymbol{i})$ & No of question $(\mathbf{N i})$ \\
\hline $\mathbf{1}$ & From Overproduction & 3 \\
$\mathbf{2}$ & From Inventory & 6 \\
$\mathbf{3}$ & From Defect & 8 \\
$\mathbf{4}$ & From Motion & 11 \\
$\mathbf{5}$ & From Transportation & 4 \\
$\mathbf{6}$ & From Process & 7 \\
$\mathbf{7}$ & From Waiting & 8 \\
$\mathbf{8}$ & To Defect & 4 \\
$\mathbf{9}$ & To Motion & 9 \\
$\mathbf{1 0}$ & To Transportation & 3 \\
$\mathbf{1 1}$ & To Waiting & 5 \\
\hline
\end{tabular}

Selanjutnya dilakukan pembobotan terhadap pemborosan secara terperinci melalui 68 jenis pertanyaan Waste Assesment Questionnaire (WAQ) dengan pengelompokan jenis dan jumlah pertanyaan pada Tabel 3 . Pembobotan ini didapatkan dari setiap jawaban responden terhadap kuesioner. Kuesioner yang diberikan bersifat assesment yang terdiri dari pertanyaan yang tidak semua orang memahaminya maka dibutuhkan pemahaman yang baik terhadap proses produksi. Oleh karena itu responden yang dipilih untuk mengisi kuesioner adalah seorang manager produksi. Setelah mendapatkan hasil akhir dari proses pembobotan dengan menggunakan WRM dan WAQ, langkah selanjutnya yang dilakukan adalah pemilihan detail mapping tools yang tepat sesuai dengan jenis pemborosan yang terjadi pada perusahaan. Proses pemilihan ini dilakukan dengan menggunakan VALSAT.

Tahap analisis merupakan analisis mengenai hasil dari pengolahan data dari pemetaan aliran proses produksi VSM, penentuan pemborosan dominan dari WAM dan VALSAT, serta penentuan akar penyebab dari pemborosan yang dominan terjadi dengan diagram fishbone untuk mendapatkan alternatif solusi perbaikan pada sistem produksi.

\section{HASIL DAN PEMBAHASAN}

Setelah didapatkan data-data yang mendukung dalam penyusunan VSM, langkah selanjutnya yaitu menyusun VSM saat ini (current state) (Martin dan Osterling, 2014) untuk proses produksi piece pivot. Dari Gambar 2 dapat dikatakan current state VSM yang menunjukan kondisi aktual yang terjadi pada lantai produksi produk piece pivot. Pada gambar tersebut bermula dari pelanggan yang melakukan melakukan pemesanan melalui e- mail kepada bagian penjualan. Informasi dari bagian penjualan kemudian diteruskan kepada bagian Production Planning and Inventory Control (PPIC), pemesanan dilakukan dengan frekuensi satu bulan sekali. Pada akhirnya, informasi ini akan dibuat Material Requirement Planning (MRP) dan Master Production Scheduling (MPS) dengan Bill of Material (BOM) sehingga baru diterbitkan Purchasing Order (PO). Dari informasi ini pun perusahaan membuat perencanaan produksi selama 22 hari kerja yang hasilnya berupa rencana target Gross Stoke per Hour (GSPH) harian.

Dari VSM dapat diketahui pula bahwasanya terdapat WIP part pada setiap proses. jumlah WIP part yang paling besar yaitu diantara proses blank dan pierching I. Hal itu terjadi karena proses cycle time dari proses pierching $I$ lebih lama dibandingkan dengan proses blank. Diperparah dengan penggantian dies yang lama dan mengganggu proses yang lainnya.

WAM merupakan suatu model yang dikembangkan untuk menyederhanakan pencarian dari permasalahan pemborosan dan mengindetifikasi untuk mengeliminasi pemborosan. (Rawabdeh, 2005). Hasil dari penyebaran kuesioner penilaian terhadap manajer produksi.

Dari Gambar 3 dapat kita lihat pembobotan pemborosan yang tertinggi sampai yang terendah untuk mengetahui pemborosan yang dominan terjadi di lantai produksi piece pivot. Urutan persentase hasil pembobotan dari yang tertinggi hingga terendah di antara 7 pemborosan, yaitu persediaan (22\%), gerakan $(18 \%)$, transportasi $(16 \%)$, produksi yang berlebihan $(14 \%)$, cacat produk $(12 \%)$, waktu menunggu (10\%), proses yang berlebihan (8\%). Pada prinsipnya Value Stream Analyze Tools (VALSAT) digunakan sebagai alat bantu untuk memetakan secara detail aliran nilai (value stream) yang berfokus pada proses penambahan nilai. Terdapat 7 macam detail mapping tools namun hanya 1 yang dipilih untuk memetakan secara detail. Total proses dari produksi piece pivot ini terdapat 47 langkah pengerjaan (Hines dan Rich, 1997). Secara detail proporsi dari setiap jenis aktivitas dan klasifikasi. 


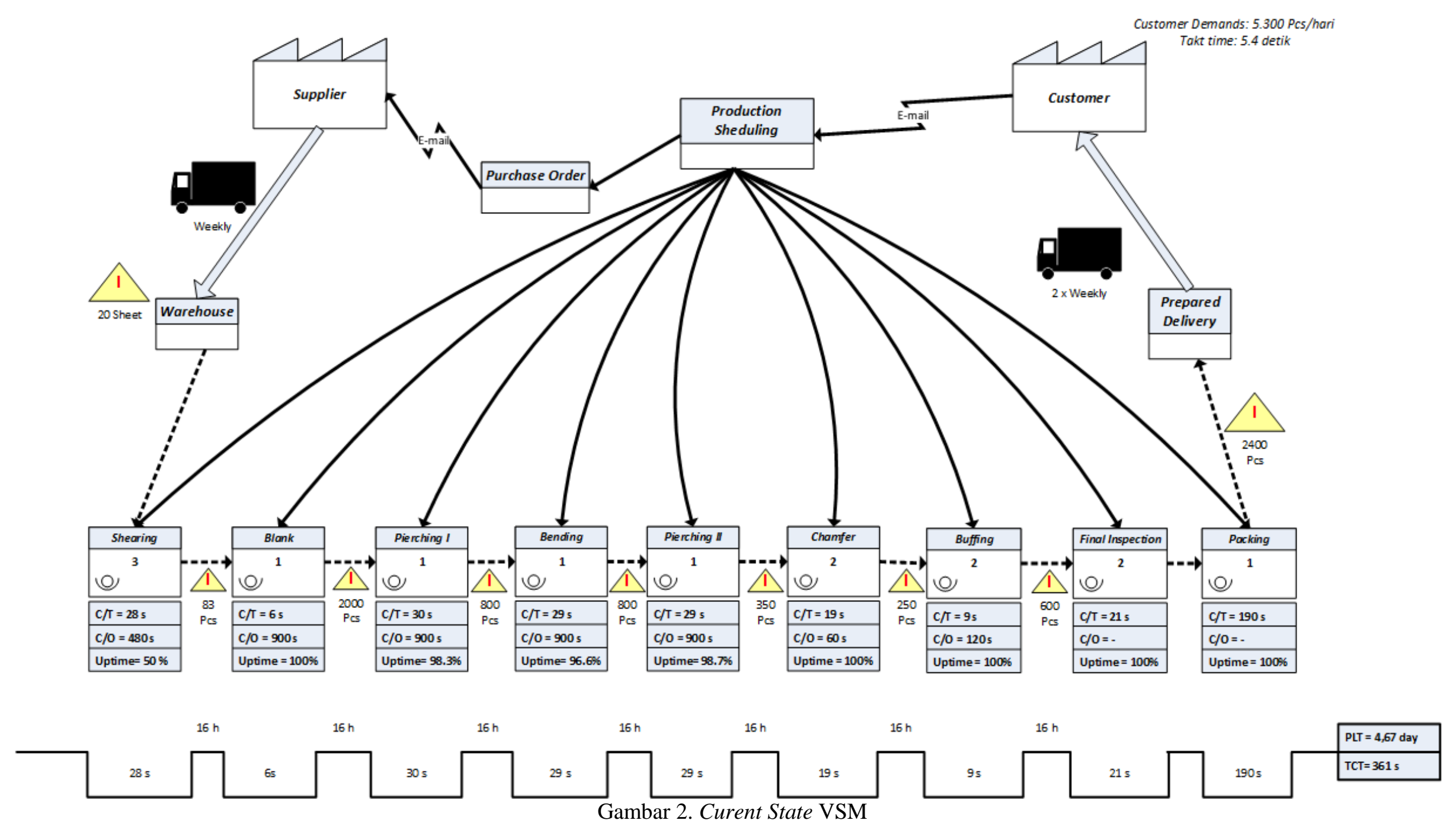




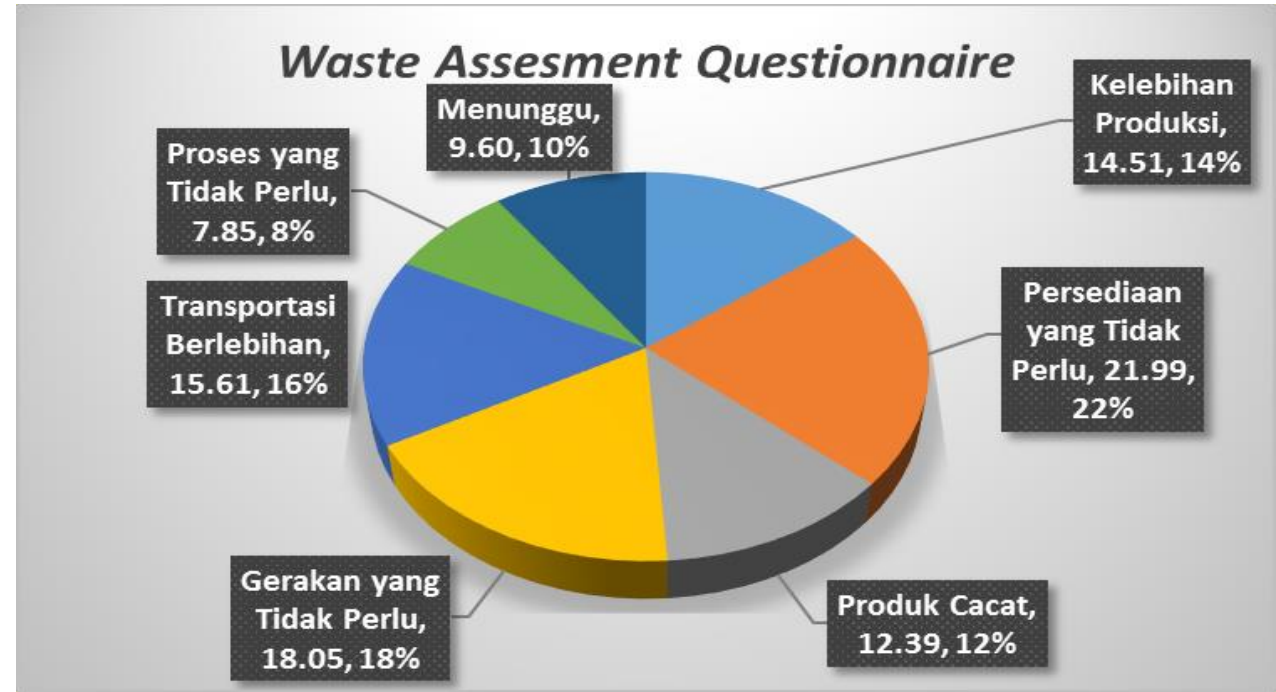

Gambar 3. Grafik Hasil Waste Assessment Questionaire (WAQ)

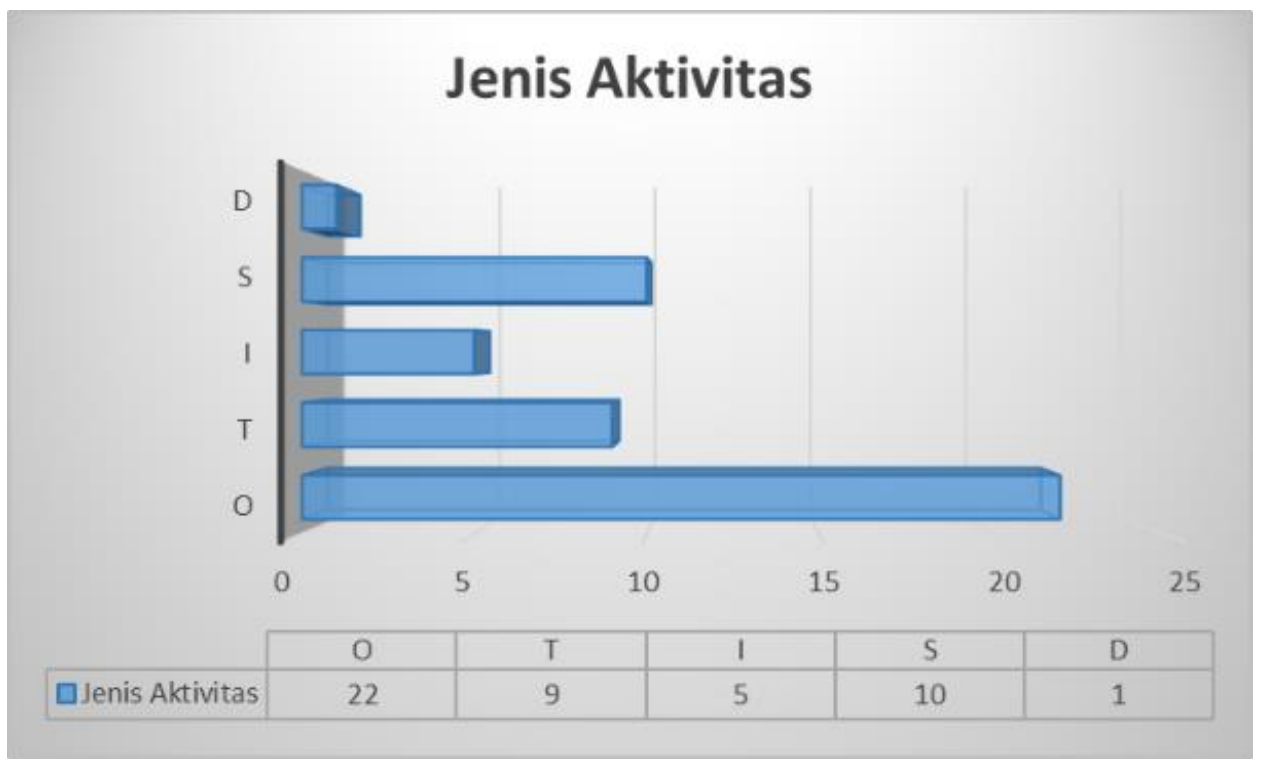

Gambar 4. Grafik Jenis Aktivitas

Tabel 4. Rekapitulasi Process Activity Mapping

\begin{tabular}{cccccc}
\hline Jenis Aktivitas & Operasi & Trans portasi & Inspeksi & Storage & Delay \\
\hline Jumlah Aktivitas & 22 & 9 & 5 & 10 & 1 \\
\hline \hline Presentase & $\mathbf{4 7 \%}$ & $\mathbf{1 9 \%}$ & $\mathbf{1 1 \%}$ & $\mathbf{2 1 \%}$ & $\mathbf{2 \%}$
\end{tabular}

Dari Gambar 4 dapat kita lihat bahwa langkah kerja yang termasuk jenis proses operation sebanyak 22 proses, transportation 9 proses, inspection sebanyak 5 proses, storage 10 proses dan terakhir delay sebanyak 1 proses. Untuk pembagian klasifikasi berdasarkan perlakuan terhadap produk dapat dilihat pada Tabel 4.

Dapat disimpulkan berdasarkan Tabel 4 dan Gambar 4 terlihat bahwa waktu aktivitas yang merupakan Value Added (VA) selama 890.77 detik dengan 12 proses aktivitas. Sementara itu, aktivitas Non Value Added (NVA) membutuhkan waktu selama 56.03 detik dengan 6 proses aktivitas dan Necessary but Non Value Added (NNVA) selama 3083.46 detik dengan 29 proses aktivitas. 


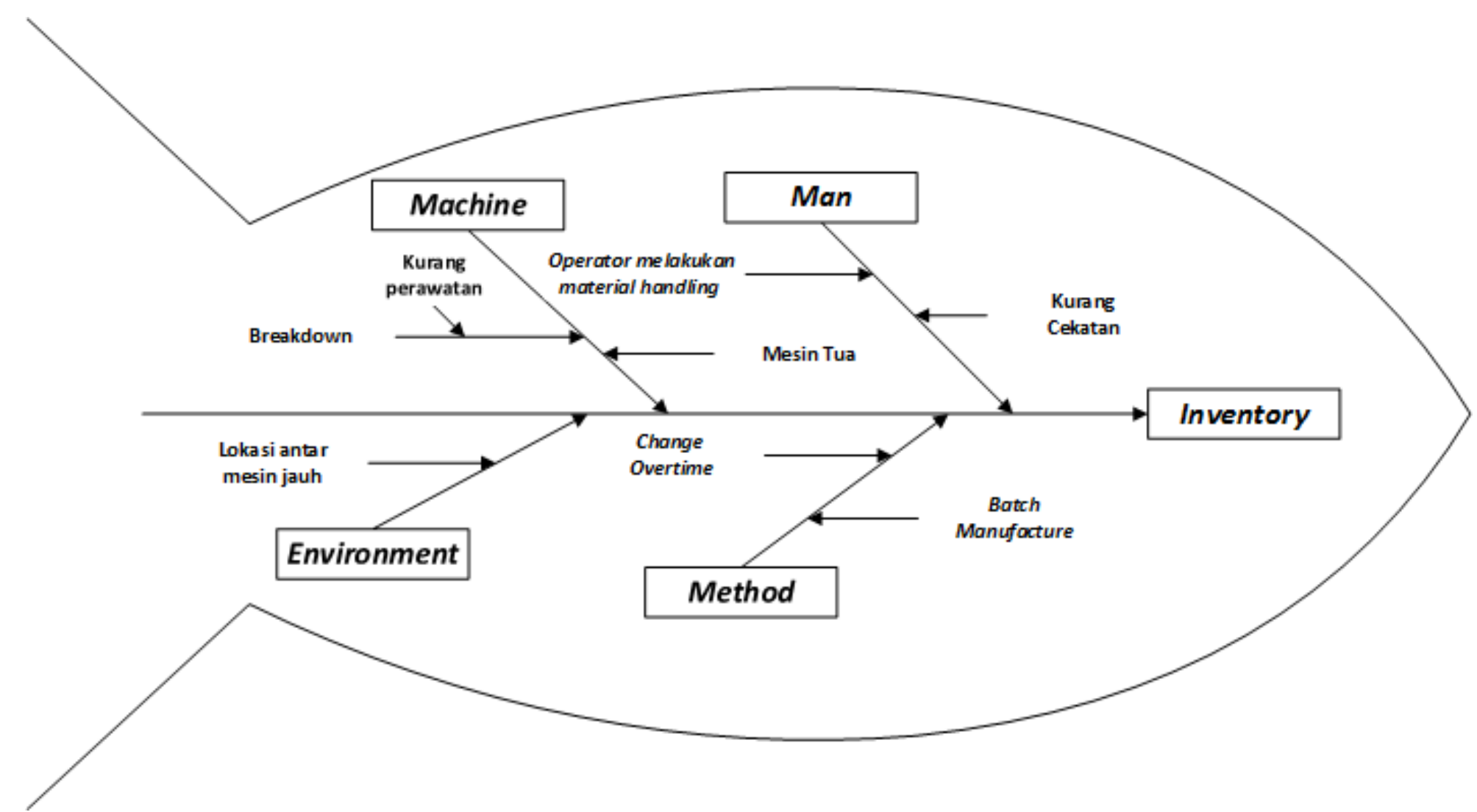

Gambar 5. Diagram Fishbone 
Persentase klasifikasi aktivitas diantara ketiga klasifikasi VA, NVA, dan NNVA masing-masing bernilai 26\%, 13\%, dan 62\% secara berurutan. Pada aktivitas proses produksi piece pivot ini NNVA merupakan aktivitas dengan persentase tertinggi. Hal ini membuktikan bahwa perusahaan memiliki banyak aktivitas yang sebenarnya tidak memberikan nilai tambah, namun tetap perlu untuk dilakukan. Tingginya persentase aktivitas NNVA disebabkan oleh banyaknya proses penanganan material (material handling).

Meskipun klasifikasi aktivitas NVA merupakan persentase terendah, Akan tetapi harus langsung segera dieliminasi karena hal ini merupakan aktivitas yang tidak bernilai tambah. Sebenarnya, tanpa aktivitas ini pun proses produksi masih dapat berjalan dengan baik (Gaspersz, 2007).

Diagram fishbone merupakan diagram yang menunjukkan penyebab dari suatu kejadian yang spesifik (Doggett, 2005). Berdasarkan Gambar 3, pemborosan dominan yang terjadi adalah persediaan, sehingga dicari akar penyebab masalah dari pemborosan tersebut.

Dari Gambar 5 dapat disimpulkan bahwa operator yang juga melakukan proses penanganan bahan baku (material handling), dengan kondisi kecepatan pengerjaan operator berbeda satu dengan yang lain karena operator kurang fokus, lelah atau sedang tidak fit. Mesin yang digunakan merupakan mesin yang sudah tua dan kurangnya perawatan mesin karena perusahaan tidak memiliki bagian khusus perawatan. Lokasi jarak antar proses yang satu dengan yang lain cukup jauh sehingga cukup memakan waktu. Change overtime yang lama karena menggunakan alat bantu forklift yang cukup besar masuk ke area produksi, menggangu proses produksi lainnya yang terpaksa juga harus berhenti sejenak karena penggantian dies mesin yang lain. Selain itu metode proses produksi yang digunakan untuk memproduksi piece pivot adalah metode batch yang berdampak pada terdapatnya WIP part diantara setiap proses.

Setelah menganalisis penyebab terjadinya pemborosan yang ada pada lantai produksi piece pivot, maka dilakukan perancangan perbaikan pada proses produksi guna mengurangi pemborosan yang terjadi pada saat ini. Adapun rekomendasinya adalah menambah sumber daya manusia pada divisi perawatan (maintenance) dan melakukan produksi menggunakan sistem one-piece flow dengan berinvestasi membeli mesin stamping transfere die.

\section{SIMPULAN}

Hasil identifikasi aktivitas pemborosan yang terjadi pada lantai produksi piece pivot yaitu: Berdasarkan VSM, ditemukan bahwa terdapat uptime mesin shearing sebesar 50\% yang menyebabkan kerugian waktu dan biaya karena harus melakukan proses shearing di perusahaan lain sehingga dampaknya proses produksi berhenti untuk sementara waktu dan bahan baku menumpuk. Terdapat WIP part pada setiap proses produksi dengan jumlah WIP part yang cukup banyak yang merupakan salah satu aktivitas pemborosan. Berdasarkan WAM, persediaan merupakan pemborosan yang dominan dengan nilai persentase tertinggi yaitu sebesar 22\% diantara jenis pemborosan yang lain. Berdasarkan VALSAT, persentase klasifikasi aktivitas diantara ketiga klasifikasi VA, NVA, dan NNVA masing-masing bernilai $26 \%$, 13\%, dan $62 \%$ secara berurutan dan penelitian ini mengeliminasi seluruh aktivitas NVA.

Hasil identifikasi faktor penyebab masalah dari aktivitas pemborosan yang dominan yaitu pemborosan persediaan menggunakan diagram fishbone adalah kurang perawatan mesin karena tidak memiliki divisi perawatan (maintenance) dan sistem produksi yang dipakai adalah batch yang memproduksi barang secara lot size sehingga terdapat WIP part pada setiap proses produksi.

Hasil perancangan perbaikan untuk mengeliminasi pemborosan yang terjadi pada lantai produksi piece pivot. dapat dijadikan rekomendasi perbaikan pada perusahaan. Rekomendasi tersebut antara lain menambah sumber daya manusia dan merubah sistem produksi menjadi one-piece flow dengan berinvestasi membeli mesin stamping transfere die. Perlu dilakukan uji coba implementasinya, guna mengetahui seberapa besar pengaruh hasil perancangan perbaikan, untuk meningkatkan produktivitas.

\section{DAFTAR PUSTAKA}

Badan Pusat Statistik (2018) Berita Resmi Statistik Pertumbuhan Produksi Industri Manufaktur Triwulan IV-2017. Jakarta. Tersedia pada: https://www.bps.go.id/pressrelease/2018/ 02/01/1479/pertumbuhan-produksi- 
industri-manufaktur-besar-dan-sedangtriwulan-iv-tahun-2017-naik-sebesar-515-persen-dan-pertumbuhan-produksiindustri-manufaktur-mikro-dan-keciltriwulan-iv-2017-naik-sebesar-4-59-pe.

Doggett, A. M. (2005) "Root Cause Analysis: A Framework for Tool Selection," Quality Management Journal, 12(4), hal. 34-45. doi: 10.1080/10686967.2005.11919269.

Fanani, Z. dan Singgih, M. L. (2011) "Implementasi Lean Manufacturing untuk Peningkatan Produktivitas (Studi Kasus pada PT. Ekamas Fortuna Malang)," in Prosiding Seminar Nasional Manajemen Teknologi XIII. Surabaya: Program Studi MMT-ITS. Tersedia pada: http://mmt.its.ac.id/download/SEMNAS/ SEMNAS XIII/MI/44. Prosiding Zaenal Fanani-OK-PRINT.pdf.

Gaspersz, V. (2007) The Executive Guide to Implementing Lean Six Sigma. Jakarta: Gramedia Pustaka Utama.

Hines, P. dan Rich, N. (1997) "The Seven Value Stream Mapping Tools," International Journal of Operations and Production Management, 17(1), hal. 46-64. doi: 10.1108/01443579710157989.

Kusuma, S. A. (2010) Penerapan Lean Manufacturing dalam Mengidentifikasi dan Meminimasi Waste di PT. Hilton
Surabaya. Universitas Pembangunan Nasional "Veteran" Jawa Timur.

Martin, K. dan Osterling, M. (2014) Value Stream Mapping. New York: McGrawHill.

Nash, M. A. dan Poling, S. R. (2008) Mapping the Total Value Stream. New York: CRC Press.

Rawabdeh, I. A. (2005) "A Model for the Assessment of Waste in Job Shop Environments," International Journal of Operations and Production Management, 25(8), hal. 800-822. doi: $10.1108 / 01443570510608619$.

Rother, M. dan Shook, J. (1999) Learning to See Value Stream Mapping to Create Value and Eliminate Muda. 1 ed. Brookline: The Lean Enterprise Institute.

Utama, D. M., Dewi, S. K. dan Mawarti, V. I. (2016) "Identifikasi Waste pada Proses Produksi Key Set Clarinet dengan Pendekatan Lean Manufacturing," Jurnal Ilmiah Teknik Industri, 15(1), hal. 36-46. doi: 10.23917/jiti.v15i1.1572.

Womack, J. P. dan Jones, D. T. (2003) Lean Thinking: Banish Waste and Create Wealth in Your Corporation. 2 ed. New York: Free Press. doi: 10.1007/BF01807056. 